\title{
Human leptin receptor gene in obese Japanese subjects: evidence against either obesity-causing mutations or association of sequence variants with obesity
}

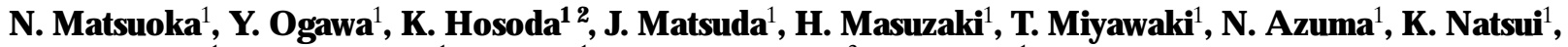

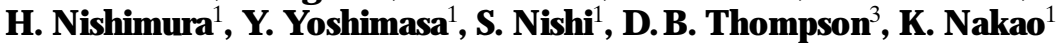 \\ ${ }^{1}$ Department of Medicine and Clinical Science, Kyoto University Graduate School of Medicine, Kyoto, Japan \\ ${ }^{2}$ Kyoto University Graduate School of Human and Environmental Studies, Kyoto, Japan \\ ${ }^{3}$ Clinical Diabetes and Nutrition Section, National Institute Diabetes and Digestive and Kidney Diseases, \\ National Institute of Health, Phoenix, Arizona, USA
}

Summary Leptin is an adipocyte-derived bloodborne satiety factor that acts on its cognate leptin receptor $(\mathrm{Ob}-\mathrm{R})$ in the hypothalamus, thereby regulating food intake and energy expenditure. To explore whether mutations in the Ob-R gene cause obesity in humans, we have searched for mutations in the gene for $\mathrm{Ob}-\mathrm{Rb}$, a biologically active receptor isoform, in obese Japanese subjects. We have also examined associations between such mutants and obesity in the Japanese. Genomic DNAs were used as templates in polymerase chain reaction (PCR) with primers selected to amplify exons 2 to 20 of the human Ob-Rb gene. Direct sequence analysis of the PCR products revealed 7 nucleotide sequence variants (Lys109Arg, Gln223Arg, Ser343Ser, Ser492Thr, Lys656Asn, Ala976Asp, and Pro1019Pro) in the Ob-Rb coding region from 17 obese Japanese subjects with a family history of obesity (BMI $39.3 \pm 8.4 \mathrm{~kg} / \mathrm{m}^{2}$ ). No missense and nonsense mutations were found such as those in Zucker fatty ( $\mathrm{fa} / \mathrm{fa})$ rats and Koletsky $\left(\mathrm{fa}^{\mathrm{k}} /\right.$ $\left.\mathrm{fa}^{\mathrm{k}}\right)$ rats. Nucleotide substitutions occurred at relatively high frequencies at codons 109, 223, 976, and 1019 (79, 91, 100, and 85\%, respectively). Allele frequency of each variant determined by PCR-RFLP and PCR-single strand conformation polymorphism analyses showed no significant differences between 47 obese (BMI $35.1 \pm 6.5 \mathrm{~kg} / \mathrm{m}^{2}$ ) and 68 non-obese $\left(B M I 21.6 \pm 2.2 \mathrm{~kg} / \mathrm{m}^{2}\right)$ subjects. The present study represents the first report of sequence variants of the $\mathrm{Ob}-\mathrm{Rb}$ gene in the Japanese and provides evidence against either obesity-causing mutations or association of sequence variants with obesity in obese Japanese subjects. [Diabetologia (1997) 40: 1204-1210]

Keywords Leptin, leptin receptor, Ob-R, obesity, sequence variant.
Obesity arises from complex interactions between genetic and environmental factors, conferring a higher risk of cardiovascular and metabolic disorders such as hypertension, hyperlipidaemia, and non-insulindependent diabetes mellitus (NIDDM) [1]. The

Received: 12 March 1997 and in revised form: 19 May 1997

Corresponding author: Y. Ogawa M.D., Ph. D., Department of Medicine and Clinical Science, Kyoto University Graduate School of Medicine, 54 Shogoin Kawahara-cho, Sakyo-ku, Kyoto 606, Japan

A bbreviations: Ob-R, leptin receptor; PCR, polymerase chain reaction; db, diabetes; fa, fatty; fak, fatty Koletsky; ob, obese; PCR-SSCP, PCR-single strand conformation polymorphism; STAT, signal transducer and activator of transcription; JAK, Janus activated kinase; NIDDM, non-insulin-dependent diabetes mellitus. molecular pathogenesis of obesity is, however, largely unknown. The discovery of leptin, the obese (ob) gene product, has provided a useful molecular tool to elucidate the pathophysiology of obesity and obesity-associated diabetes [2-7]. It has been recognized that leptin is an adipocyte-derived blood-borne satiety factor that is involved in the regulation of food intake and energy expenditure [8]. The leptin receptor $(\mathrm{Ob}-\mathrm{R})$, the diabetes $(\mathrm{db})$ gene product, is a single transmembrane protein that belongs to the gp130 family of cytokine receptor superfamily [9-12]. The receptor has several alternatively spliced isoforms, one of which, a biologically active Ob-Rb isoform, is expressed most abundantly in the hypothalamus $[9,11,13-15]$. Leptin has been shown to activate signal transducers and activators of transcription (STATs) in the hypothalamus, suggesting that the 
Table 1. Clinical profiles and polymorphic nucleotides in the Ob-Rb gene from 17 obese subjects

\begin{tabular}{|c|c|c|c|c|c|c|c|c|c|c|}
\hline Sex & $\begin{array}{l}\text { Age } \\
\text { (years) }\end{array}$ & $\begin{array}{l}\mathrm{BMI}^{\mathrm{a}} \\
\left(\mathrm{kg} / \mathrm{m}^{2}\right)\end{array}$ & Complications & $\begin{array}{l}\text { Lys109Arg } \\
\text { AAG/AGG }\end{array}$ & $\begin{array}{l}\text { Gln223Arg } \\
\text { CAAG/CGGG }\end{array}$ & $\begin{array}{l}\text { Ser343Ser } \\
\text { AGT/AG } \underline{C}\end{array}$ & $\begin{array}{l}\text { Ser492Thr } \\
\text { A } \underline{G T / A} \text { CTT }\end{array}$ & $\begin{array}{l}\text { Lys656Asn } \\
\text { AAG } \underline{A A A} \underline{C}\end{array}$ & $\begin{array}{l}\text { Ala976Asp } \\
\text { GCCC/G므 }\end{array}$ & $\begin{array}{l}\text { Pro1019Pro } \\
\text { CCG/CCA }\end{array}$ \\
\hline F & 36 & 32.2 & - & $\mathrm{A} / \mathrm{G}$ & $\mathrm{G} / \mathrm{G}$ & $\mathrm{T} / \mathrm{T}$ & $\mathrm{G} / \mathrm{G}$ & $\mathrm{G} / \mathrm{G}$ & $\mathrm{A} / \mathrm{A}$ & $\mathrm{G} / \mathrm{A}$ \\
\hline $\mathrm{F}$ & 22 & 34.7 & HT & $\mathrm{A} / \mathrm{G}$ & $\mathrm{G} / \mathrm{G}$ & $\mathrm{T} / \mathrm{C}$ & $\mathrm{G} / \mathrm{G}$ & $\mathrm{G} / \mathrm{G}$ & $\mathrm{A} / \mathrm{A}$ & $\mathrm{G} / \mathrm{G}$ \\
\hline M & 25 & 38.1 & NIDDM & $\mathrm{G} / \mathrm{G}$ & $\mathrm{G} / \mathrm{G}$ & $\mathrm{T} / \mathrm{T}$ & $\mathrm{G} / \mathrm{G}$ & $\mathrm{G} / \mathrm{G}$ & $\mathrm{A} / \mathrm{A}$ & $\mathrm{A} / \mathrm{A}$ \\
\hline $\mathrm{F}$ & 55 & 29.9 & NIDDM & $\mathrm{G} / \mathrm{G}$ & $\mathrm{G} / \mathrm{G}$ & $\mathrm{T} / \mathrm{T}$ & $\mathrm{G} / \mathrm{G}$ & $\mathrm{G} / \mathrm{G}$ & $\mathrm{A} / \mathrm{A}$ & $\mathrm{A} / \mathrm{A}$ \\
\hline $\mathrm{F}$ & 55 & 27.5 & - & $\mathrm{G} / \mathrm{G}$ & $\mathrm{A} / \mathrm{G}$ & $\mathrm{T} / \mathrm{T}$ & $\mathrm{G} / \mathrm{G}$ & $\mathrm{G} / \mathrm{G}$ & $\mathrm{A} / \mathrm{A}$ & $\mathrm{G} / \mathrm{A}$ \\
\hline $\mathrm{F}$ & 20 & 33.2 & IGT & $\mathrm{A} / \mathrm{G}$ & $\mathrm{G} / \mathrm{G}$ & $\mathrm{T} / \mathrm{T}$ & $\mathrm{G} / \mathrm{C}$ & $\mathrm{G} / \mathrm{G}$ & $\mathrm{A} / \mathrm{A}$ & $\mathrm{A} / \mathrm{A}$ \\
\hline M & 50 & 42.1 & - & $\mathrm{G} / \mathrm{G}$ & $\mathrm{G} / \mathrm{G}$ & $\mathrm{T} / \mathrm{T}$ & $\mathrm{G} / \mathrm{G}$ & $\mathrm{G} / \mathrm{G}$ & $\mathrm{A} / \mathrm{A}$ & $\mathrm{A} / \mathrm{A}$ \\
\hline M & 32 & 35.6 & HL & $\mathrm{G} / \mathrm{G}$ & $\mathrm{G} / \mathrm{G}$ & $\mathrm{T} / \mathrm{T}$ & $\mathrm{G} / \mathrm{G}$ & $\mathrm{G} / \mathrm{G}$ & $\mathrm{A} / \mathrm{A}$ & $\mathrm{A} / \mathrm{A}$ \\
\hline M & 17 & 39.1 & - & $\mathrm{A} / \mathrm{G}$ & $\mathrm{G} / \mathrm{G}$ & $\mathrm{T} / \mathrm{T}$ & $\mathrm{G} / \mathrm{G}$ & $\mathrm{G} / \mathrm{G}$ & $\mathrm{A} / \mathrm{A}$ & $\mathrm{A} / \mathrm{A}$ \\
\hline $\mathrm{F}$ & 16 & 39.7 & HT & $\mathrm{G} / \mathrm{G}$ & $\mathrm{G} / \mathrm{G}$ & $\mathrm{T} / \mathrm{T}$ & $\mathrm{G} / \mathrm{G}$ & $\mathrm{G} / \mathrm{G}$ & $\mathrm{A} / \mathrm{A}$ & $\mathrm{A} / \mathrm{A}$ \\
\hline M & 25 & 51.1 & $\begin{array}{l}\text { hypothyroidism } \\
\text { hypogonadism, CHF }\end{array}$ & $\mathrm{A} / \mathrm{G}$ & $\mathrm{A} / \mathrm{A}$ & $\mathrm{T} / \mathrm{C}$ & $\mathrm{G} / \mathrm{G}$ & $\mathrm{G} / \mathrm{C}$ & $\mathrm{A} / \mathrm{A}$ & $\mathrm{G} / \mathrm{A}$ \\
\hline
\end{tabular}

Polymorphic nucleotides are underlined. IGT, impaired glucose tolerance; HT, hypertension; HL, hyperlipidaemia; CHF, congestive heart failure; - , no complications. ${ }^{\text {a }}$ BMI values are determined at the time of genotyping

hypothalamus is a major target site of leptin $[16,17]$. Indeed, we and others have recently demonstrated that leptin exerts its satiety effect by acting directly on the hypothalamus $[14,16,18,19]$. These findings suggest that leptin and Ob-R constitute an important feedback system linking the hypothalamus and adiposity, thus regulating energy homeostasis.

Synthesis and secretion of leptin are increased in several models of rodent obestity and in human obesity in proportion to disease severity [20-23]. These observations suggest that augmented production of leptin represents one of the deterrent mechanisms for the development of obesity. In some models of rodent obesity or human obesity, however, plasma leptin levels exceed those expected for the degree of adiposity or BMI [21, 22]. Since leptin causes a reduction in food intake and an increase in energy expenditure, thereby resulting in weight loss, it is speculated that obese animals and humans are resistant to endogenous leptin (a condition called leptin resistance) $[4,8,24]$.

Genetic evidence has indicated that ob/ob mice develop marked obesity and obesity-related diabetes because of a failure to produce bioactive leptin due to a nonsense mutation of the ob gene [2]. No such mutations of the ob gene were, however, found in human obesity from several ethnic groups (the Caucasian, Pima Indians, and Japanese) [25-28]. It has been shown that $\mathrm{Ob}-\mathrm{Rb}$ is missing in $\mathrm{db} / \mathrm{db}$ mice due to $\mathrm{a}$ point mutation leading to its abnormal transcript [10, 11]. Recently, we and others have demonstrated that $\mathrm{Ob}-\mathrm{R}$ is also mutated in genetically obese Zucker fatty ( $\mathrm{fa} / \mathrm{fa})$ rats and obese spontaneously hypertensive Koletsky $\left(\mathrm{fa}^{\mathrm{k}} / \mathrm{fa}^{\mathrm{k}}\right)$ rats $[13,29-31]$. For analysis of the $\mathrm{Ob}-$ $\mathrm{R}$ gene in humans, previous studies revealed several sequence polymorphisms in the $\mathrm{Ob}-\mathrm{Rb}$ gene with no obesity-causing mutations in black African-Americans, Caucasians and Pima Indians [32,33].

The present study was undertaken to search for mutations in the $\mathrm{Ob}-\mathrm{Rb}$ gene in obese Japanese subjects and to assess whether such mutations are associated with obesity in the Japanese.

\section{Subjects and methods}

Subjects: The study groups consisted of 47 obese subjects (maximum $\mathrm{BMI}>30$, mean $\pm \mathrm{SEM}, \quad 35.1 \pm 6.5 \mathrm{~kg} / \mathrm{m}^{2} ; \quad$ age $41.9 \pm 16.6$ years; NIDDM $n=13$, impaired glucose tolerance $n=3$, hypertension $n=6$, hyperlipidaemia $n=6$, osteoarthritis $n=4$, hypothyroidism $n=2$, eating disorders $n=2$ ) and 68 nonobese subjects without any endocrine and metabolic disorders (maximum $\mathrm{BMI}<25,21.6 \pm 2.2 \mathrm{~kg} / \mathrm{m}^{2}$; age $45.9 \pm 8.0$ years). The present study was conducted with informed consent and approved by the ethical committee on human research of Kyoto University Graduate School of Medicine.

Polymerase chain reaction (PCR)-direct sequence analysis: Genomic DNA was extracted from peripheral blood leukocytes according to the standard procedure. Genomic DNAs from 17 obese Japanese subjects (Table 1) with a family history of obesity (maximum $\mathrm{BMI}>30,39.3 \pm 8.4 \mathrm{~kg} / \mathrm{m}^{2}$; age $32.6 \pm 1.3$ years) were used as templates in PCR with upstream and downstream primers selected to amplify sequences corresponding to exons 2 to 20 of the human $\mathrm{Ob}-\mathrm{Rb}$ gene according to the GENBANK databank (U59247-U59263) (Fig. 1 and Table 2) [33]. The reaction profiles were as follows; denaturation at $94^{\circ} \mathrm{C}$ for $45 \mathrm{~s}$, annealing at $55^{\circ} \mathrm{C}$ for $45 \mathrm{~s}$, and extension at $72^{\circ} \mathrm{C}$ for $90 \mathrm{~s}$, for 30 cycles. All PCR products were analysed by agarose gel electrophoresis, purified, and sequenced using automated protocols of fluorescent detection of dideoxy termination products of a model 373B DNA autosequencing system (Applied Biosystems Inc., Foster City, Calif., USA). 


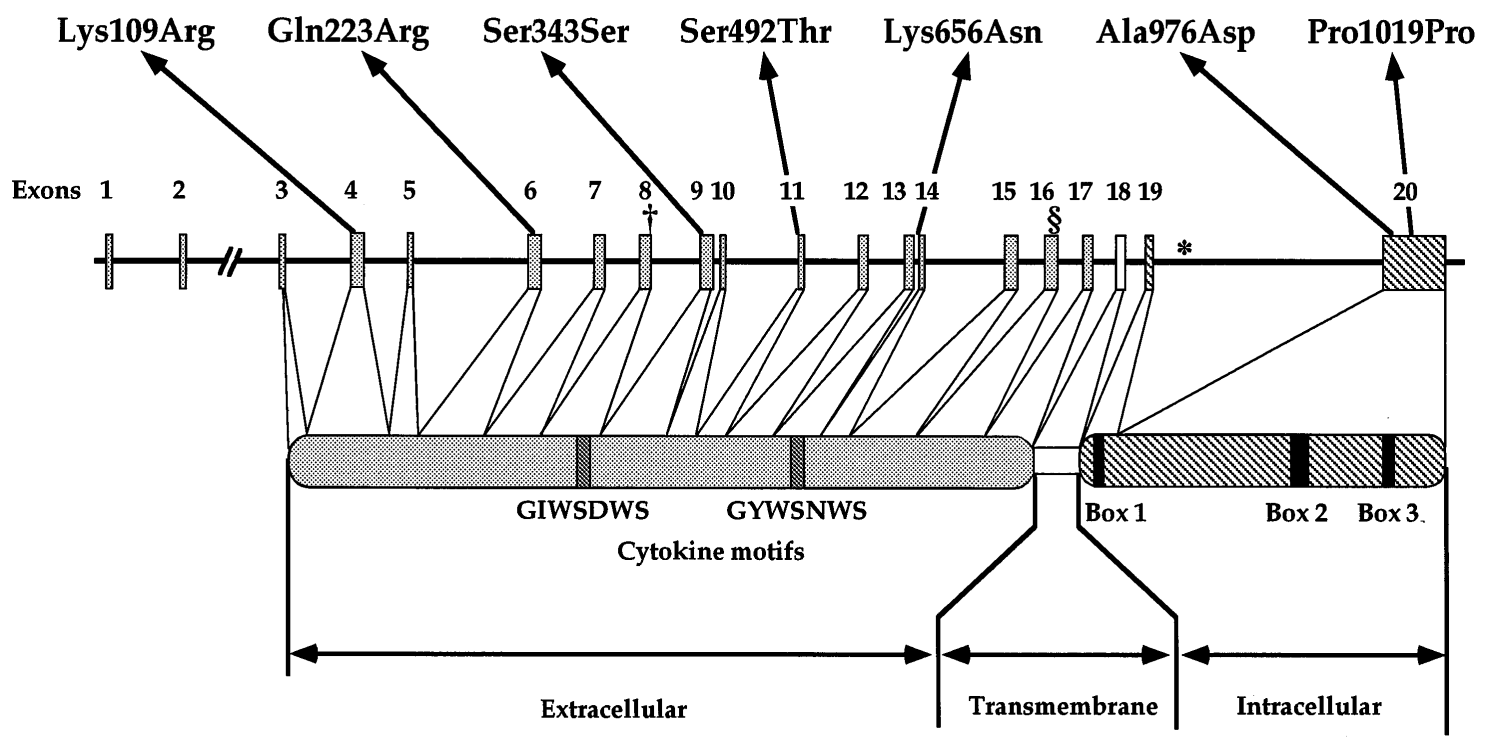

Fig. 1. Schematic representation of the Ob-Rb gene (upper panel) and its protein structure (lower panel). Genomic organization of the $\mathrm{Ob}-\mathrm{Rb}$ gene is based on the GENBANK databank data (U59247-U59263) [33]. The extracellular, transmembrane, and intracellular regions of the receptor are indicated by shaded, open, and hatched areas, respectively. Locations of two cytokine motifs (GXWSXWS) and Box 1, Box 2, and Box 3 consensus sequences are also depicted. Seven sequence variants are indicated above the $\mathrm{Ob}-\mathrm{Rb}$ gene structure. The $\mathrm{db}, \mathrm{fa}$, and $\mathrm{fa}^{\mathrm{k}}$ mutations found in genetically obese rodents $[10-13,29-31]$ are marked by $*, \dagger, \S$ respectively

PCR-RFLP analysis: PCR-RFLP analysis was performed for genotyping at codons 223, 492, 976, and 1019 (Fig.2). The PCR primers were sequence-specific and/or mutated for convenience (Fig. 2 and Table 3 ). The PCR products were digested with M sp I, Pst I, H ae III, and H inc II at codons 223, 492, 976, and 1019, respectively, and were analysed as described [13].
PCR-single strand conformation polymorphism (PCR-SSCP) analysis: PCR-SSCP analysis was used for genotyping at condons 109, 343, and 656 (Fig. 3). Fragments encompassing the polymorphic sites were amplified by PCR with sequence-specific primers (Table 3). After amplification, $3 \mu$ of each PCR reaction plus $15 \mu \mathrm{l}$ of $95 \%$ formamide $2 \mathrm{mmol} / \mathrm{l}$ EDTA loading solution was heat denatured at $85^{\circ} \mathrm{C}$ for $10 \mathrm{~min}$. Denatured samples were loaded on $10 \%$ nondenaturing polyacrylamide gels with or without $5 \%$ glycerol. Electrophoresis was done at room temperature or $4^{\circ} \mathrm{C}$ at a constant current of $10-20 \mathrm{~mA}$ for 10-16 h. The gels were stained with SYBR Green II (FMC BioProducts, Rockland, Me., USA) according to the manufacturer's recommendations.

Statistical analysis: Values are expressed as the mean \pm SEM. The statistical differences between groups in allele frequencies were assessed by Fishers's exact test. The $p$ values less than 0.05 were considered significant. All statistical procedures were performed with a statistical software package (STAT VIEW J4.02; Abacus Concepts, Inc., Berkeley, Calif., USA).

Table 2. Sequences of primer pairs for PCR-direct sequence

\begin{tabular}{|c|c|c|}
\hline & Upstream primers & Downstream primers \\
\hline \multicolumn{3}{|l|}{ Exons } \\
\hline 2 & 5'-AGAAGGTTATGCAGCCATNCTACTATC-3' & 5'-CCACAAAGGGACTGTGTTCATAAACTG-3' \\
\hline 3 & 5'TAAATTNAGAGACTTATCTATAATCCC-3' & 5'-TAACTAGAAATAGGAAATTCTGTTAGC-3' \\
\hline 5 & 5'-TTTTTTTTAATTCAGATGCAAACTGGA-3' & 5'-TGCAAGAGGTTTATAATCTACTTTCCGT-3' \\
\hline 6 & 5'-ACССТTTAAGCTGGGTGTCCCAAATAG-3' & 5'-AGCTAGCAAATATTTTTGTAAGCAATT-3' \\
\hline 7 & 5'-TGACTTTATTTTATTCAGCTATAATTG-3', & 5'-GTAATTGCTATGGGACTTAAGAGGGTC-3' \\
\hline 11 & 5'-GACTGCTGTTTTAAACAACAAATCAG-3', & 5'-CTGCATACAAATCTGCTAACACAAATG-3' \\
\hline 12 & 5'-TGAAAATATAACACAATGTTTTTAGGC-3' & 5'-TTTATGCCAATAAAATTAATCTAATGC-3' \\
\hline $13-14$ & 5'-GGTTTAAAATAAAATGTACTTCAGGGC-3' & 5'-TGGACCATGAAGTCTTTTTAAGAGTA-3' \\
\hline 15 & 5'-GAGACTGTGGCAGAGGCAAACTATATC-3' & 5'-ATTGCAGGCTGCTTGAAAGATAATTTA-3' \\
\hline 16 & 5'-TTCССTTTAGTAGGTTATAAGTTCCTC-3', & 5'-TTTTTGAAGTTTTCATTAACTGGCTAT-3' \\
\hline 17 & 5'-TTTGGAAACTCCCTTGATAATTTAATC-3', & 5'-ССТСАССАТGAАAАATCTACAGAAGAC-3' \\
\hline
\end{tabular}




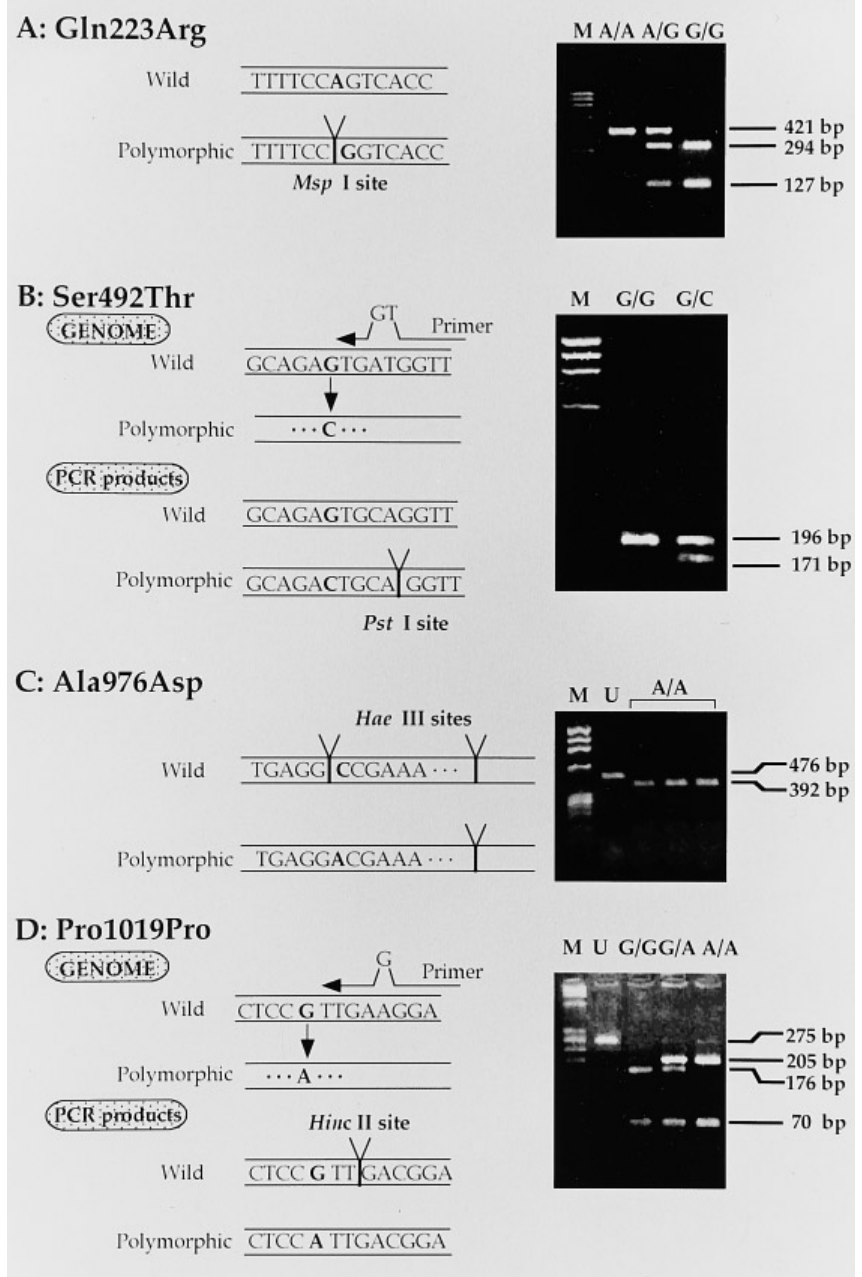

Fig. 2A - D. Genotyping of the polymorphic alleles in the Ob$\mathrm{Rb}$ gene by PCR-RFLP at codons 223 (nucleotide 668) (A), 492 (1475) (B), 976 (2927) (C), and 1019 (3057) (D), where A to $\mathrm{G}, \mathrm{G}$ to $\mathrm{C}, \mathrm{C}$ to $\mathrm{A}$, and $\mathrm{G}$ to $\mathrm{A}$ transversions occurred, respectively. (Left) Schematic representation of wild and polymorphic alleles. PCR-RFLP analyses were performed using upstream and downstream sequence-specific primers (for Gln223Arg and Ala976Asp) (A and C) or upstream sequence-specific and downstream mutated primers (for Ser492Thr and Pro1019Pro) (B and D) as described in Subjects and methods. The restriction sites created (M sp I (A) and P st I (B)) and those abolished (H ae III (C) and $\mathrm{H}$ inc II (D)) in polymorphic alleles were depicted. Polymorphic nucleotides are shown in bold. (Right) Gel electrophoresis of the PCR products after digestion with restriction enzymes. The cytosine allele reported at codon 976 [9] was not observed in the present study (Table 4). Genotypes are indicated by $\mathrm{N} / \mathrm{N}(\mathrm{N}=\mathrm{A}, \mathrm{C}$, G). M; DNA size marker $\varphi \mathrm{X} 174-\mathrm{H}$ ae III digest. U; uncut PCR products. bp; basepair

\section{Results}

I dentification of sequence variants in obese subjects. Direct sequence analysis of the PCR products revealed 7 nucleotide sequence variants in the $\mathrm{Ob}-\mathrm{Rb}$ coding region from 17 obese Japanese subjects. In the present study, there were no such mutations as those found in Zucker fatty ( $\mathrm{fa} / \mathrm{fa}$ ) rats and Koletsky $\left(\mathrm{fa}^{\mathrm{k}} / \mathrm{fa}^{\mathrm{k}}\right)$ rats $(\mathrm{G} \ln 269$ Pro and Tyr763Stop, respectively) (Fig. 1) [13, 29-31]. At nucleotide 326 (codon 109 ) in exon 4 , an $A$ to $G$ transversion resulted in Lys109Arg substitution. Another A to $G$ transversion was found at nucleotide 668 (codon 223) in exon 6, producing Gln223Arg, which was reported previously $[32,33]$. This substitution created a new M sp I restriction site (Fig. 2A). In all 17 obese subjects examined at codon 976 in exon 20, Ala was changed to Asp (Ala976Asp) due to a transversion from C to A at nucleotide 2927, which abolished an $\mathrm{H}$ ae III site (Fig. 2C). At nucleotide 3057 (codon 1019), a G to A transversion was found, which caused no amino acid substitution. These 4 polymorphic alleles occurred at high frequencies in 17 obese subjects examined (79, 91, 100, and $85 \%$ for Lys109Arg, Gln223Arg, Ala976Asp, and Pro1019Pro, respectively). Three other substitutions, Ser343Ser ( $\mathrm{T}$ to $\mathrm{C}$ at nucleotide 1029), Ser492Thr ( $G$ to $C$ at nucleotide 1475), and Lys656Asn ( $\mathrm{G}$ to $\mathrm{C}$ at nucleotide 1968) were observed at relatively low frequencies $(1,2$, and 3 heterozygotes out of 17 subjects, respectively). No other sequence variants were found in the $\mathrm{Ob}-\mathrm{Rb}$ coding region compared to the human $\mathrm{Ob}-\mathrm{Rb} \mathrm{cDNA}$ sequences reported previously [9].

A llele frequencies in obese and non-obese subjects. To investigate whether the $\mathrm{Ob}-\mathrm{Rb}$ gene polymorphisms identified are related to obesity in the Japanese, we examined allele frequencies of sequence variants in 47 obese subjects compared to those in 68 non-obese subjects (Table 4). Genotypes of polymorphic sites were determined by PCR-RFLP at codons 223, 492, 976, and 1019 (Fig. 2) and by PCR-SSCP at codons 109, 343, and 656 (Fig. 3). In 47 obese subjects (BMI $35.1 \pm 6.5 \mathrm{~kg} / \mathrm{m}^{2}$ ), allele frequencies of polymorphic sites at codons 109, 223, and 1019 (Gly109Arg, Gln223Arg, and Pro1019Pro) were 82, 87, and 88\% respectively. In 68 non-obese subjects (BMI $21.6 \pm 2.2 \mathrm{~kg} / \mathrm{m}^{2}$ ), they were 77,84 , and $88 \%$, respectively. No significant differences in frequency of each allele were observed between obese and non-obese groups $(p=0.41,0.57$, and $>0.99$, respectively). Allele frequencies in sequence variants at codons 109 , 223, and 1019 in all the subjects examined were 79 , 85 , and $88 \%$ respectively. The sequence variants were also reported in Pima Indians $(58,75$, and $85 \%$, respectively) and Caucasians $(28,44$, and $37 \%$, respectively) [33]. The Ala976Asp variant was observed in all the subjects analysed (Table 4); no one carried the previously reported Ala allele [9]. Other polymorphisms (Ser343Ser, Ser492Thr, Lys656Asn) were detected with no significant differences in allele frequency between obese and non-obese groups (Ser343Ser 11 vs 9\%, $p=0.66$; Ser492Thr 1 vs $0 \%, p=0.41$; Lys656Asn 10 vs $14 \%, p=0.41$ ). In the present study, sequence variants at codons 109 , 


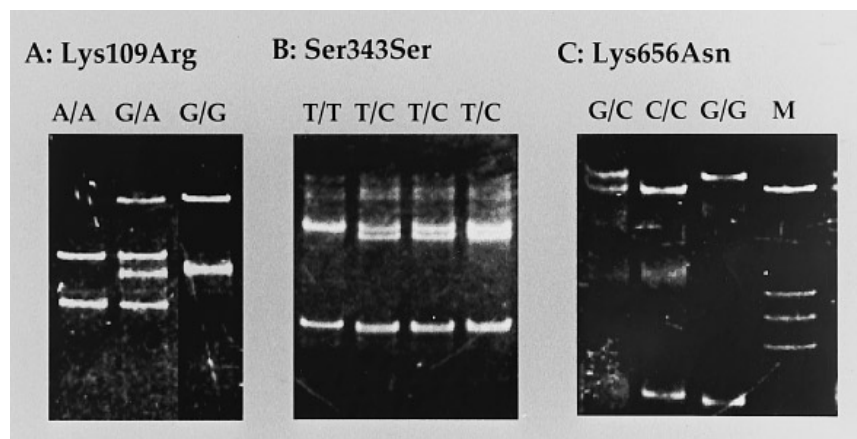

Fig. 3A-C. Genotyping of polymorphic sites in the $\mathrm{Ob}-\mathrm{Rb}$ gene by PCR-SSCP at codons 109 (nucleotide 326) (A), 343 (1029) (B), and 656 (1968) (C), where G to A, T to C, and G to $\mathrm{C}$ transversions occurred, respectively. Genotypes are indicated by $\mathrm{N} / \mathrm{N}(\mathrm{N}=\mathrm{A}, \mathrm{C}, \mathrm{G}, \mathrm{T})$. $\mathrm{M}$; undenatured DNA size marker $\varphi \mathrm{X} 174-\mathrm{H}$ ae III digest

223, 656, 976, and 1019 were found to be homozygous in both obese and non-obese subjects. Sequence variants at codons 343 and 492 were found to be only heterozygous.

\section{Discussion}

We have searched here for mutations in the $\mathrm{Ob}-\mathrm{Rb}$ gene from 17 obese Japanese subjects and found 7 sequence variants in its coding region. In the present study, 4 amino acid substitutions (Lys109Arg, Gln223Arg, Ser492Thr, and Lys656Asn) were located in the extracellular region of $\mathrm{Ob}-\mathrm{Rb}$. An amino acid substitution (Ala976Asp) was found in the intracellular region. Ob-Rb contains several functionally important domains; it contains 2 cytokine motifs (GXWSXWS) in the extracellular region (Fig.1), which are implicated in the ligand binding [9]. In the intracellular region, it contains Box 1, Box 2, and Box 3 consensus sequences, which are involved in interactions with Janus activated kinase (JAK) and STATs $[9,34]$. No sequence variants were, however, located in such functionally defined domains (Fig. 1). Genetic evidence showed that $\mathrm{ob}, \mathrm{db}, \mathrm{fa}$, and $\mathrm{fa}^{\mathrm{k}}$, all of which code for leptin or Ob-R, are autosomal recessive mutations in rodents [2,10-13, 29-31]. In the present study, 4 amino acid substitutions (Lys109Arg, Gln223Arg, Lys656Asn, and Ala976Asp) were found to be homozygous but were distributed in both obese and non-obese subjects. The amino acid change at codon 492 (Ser492Thr) was found to be only heterozygous. These observations, taken together, suggest that, unlike genetically obese animals, sequence variants identified in the present study are not obesitycausing mutations. The discussion above, however, does not rule out the possibility of a compound heterozygotic mechanism [35], in which a missense mutation in one allele may cause obesity in combination with an as yet unidentified mutation in the other allele (possibly to be found in the promoter and/or intron sequences).

The present study revealed no significant differences in allele frequency of each of 7 sequence variants between obese and non-obese subjects. These results are consistent with a recent report that sequence variants in the $\mathrm{Ob}-\mathrm{Rb}$ coding region are not linked with obesity in Pima Indians and Caucasians [33]. The findings, taken together, suggest that sequence variants in the $\mathrm{Ob}-\mathrm{Rb}$ coding region are not strongly associated with obesity. In this regard, the sequence variants identified may not be used as markers for other mutations involved in the development of obesity.

It was reported that $\mathrm{db} / \mathrm{db}$ mice carry a point mutation in intron 19 of the Ob-Rb gene (Fig. 1), which results in an abnormal splice acceptor site, thereby leading to the absence of $\mathrm{Ob}-\mathrm{Rb}$ in these animals $[10,11]$. Considine et al. [32] previously showed in 15 African-Americans no mutations such as those found in $\mathrm{db} / \mathrm{db}$ mice. Furthermore, the authors found no correlation between the amount of hypothalamic $\mathrm{Ob}-\mathrm{Rb} \mathrm{mRNA}$ and BMI. In the present study, we have mainly examined the human Ob-Rb coding region and have not analysed the promoter and intron sequences of the $\mathrm{Ob}-\mathrm{Rb}$ gene. Whether mutations occur in the promoter and/or intron sequences of the $\mathrm{Ob}-\mathrm{Rb}$ gene from obese Japanese subjects must await further investigations.

Table 3. Sequences of primer pairs for PCR-RFLP and PCR-SSCP

\begin{tabular}{|c|c|c|}
\hline & Upstream primers & Downstream primers \\
\hline \multicolumn{3}{|l|}{ PCR-RFLP } \\
\hline Gln223Arg & 5'-ACССТTTAAGCTGGGTGTCCCAAATAG-3' & 5'-AGCTAGCAAATATTTTTGTAAGCAATT-3' \\
\hline Ser492Thr & 5'-GTATACTAATTGACTATTTTTGTATCT-3' & 5'-GGCTGGAAAATGCATTCATAAAAACCTGCA-3' \\
\hline Pro1019Pro & 5'-GAAACTGGTGAAGAACAAGGGCTTATAAAT-3' & 5'-CCATGAGCTATTAGAGAAAGAATCCGTCAA-3 ${ }^{\prime a}$ \\
\hline \multicolumn{3}{|l|}{ PCR-SSCP } \\
\hline Lys109Arg & 5'-CCTGCTGGACTCTCAAAGAA-3' & 5'-TGTTAAAATCATAGCCATAAGACATCT-3' \\
\hline
\end{tabular}

a To make restriction sites, these primers are synthesized with mutations (underlined) 
Table 4. Allele frequencies of polymorphic sites

\begin{tabular}{llllllll}
\hline Codons & 109 & 223 & 343 & 492 & 656 & 976 \\
\hline $\begin{array}{l}\text { Obese } \\
(\mathrm{n}=47)\end{array}$ & A 0.181 & A 0.128 & T 0.894 & G 0.989 & G 0.904 & C 0.00 & G 0.117 \\
& G 0.819 & G 0.872 & C 0.106 & C 0.011 & C 0.096 & A 1.00 & A 0.883 \\
$\begin{array}{l}\text { Non-obese } \\
(n=68)\end{array}$ & A 0.235 & A 0.162 & T 0.912 & G 1.00 & G 0.860 & C 0.00 & G 0.118 \\
& G 0.765 & G 0.838 & C 0.088 & C 0.00 & C 0.140 & A 1.00 & A 0.882 \\
p value & 0.41 & 0.57 & 0.66 & 0.41 & 0.41 & $>0.99$ & $>0.99$ \\
\hline
\end{tabular}

Nucleotides reported [9] and those identified in the present study are in upper and lower portions, respectively

In conclusion, we have identified 7 sequence variants in the human $\mathrm{Ob}-\mathrm{Rb}$ coding region and provided evidence against either obesity-causing mutations or association of sequence variants with obesity in obese Japanese subjects. The present study represents the first report of sequence variants in the $\mathrm{Ob}-\mathrm{Rb}$ gene in the Japanese, thereby providing a genetic basis for the Ob-R gene research in humans.

A cknowledgements. We would like to thank Dr. T. Shirakawa of the Lung Research Unit, Churchill Hospital, University of Oxford for valuable advice and critical reading of this manuscript, Dr. T. Matsuo and Dr. A. Sugawara of Osaka Saiseikai Nakatsu Hospital, Dr. M. Imura of Yaizu Municipal General Hospital, Dr. Y. Hasegawa of Tokyo Metropolitan Kiyose Children's Hospital, Dr. S. Nakaishi of Osaka Red Cross Hospital, Y. Harano of the National Cardiovascular Center, Dr. Y. Toda of Kansai Medical College, and Dr. M. Okubo of Toranomon Hospital for collecting genomic DNA samples. The authors also thank Ms. K. Hiramatsu and Ms. C. Kawahara for their secretarial assistance. This work was supported in part by research grants from the Japanese Ministry of Education, Science and Culture, the Japanese Ministry of Health and Welfare, Yamanouchi Foundation for Research on Metabolic Disorders, Uehara Memorial Foundation, and a grant for diabetes research for Otsuka Pharmaceutical Co., Ltd., Tokushima, Japan.

\section{References}

1. Björntorp P, Brodoff BN (1992) Obesity. JB Lippincott Company, Philadelphia

2. Zhang Y, Proenca R, Maffei M, Barone M, Leopold L, Friedman JM (1994) Positional cloning of the mouse obese gene and its human homologue. Nature 372: 425-432

3. Spiegelman BM, Flier JS (1996) Adipogenesis and obesity: rounding out the big picture. Cell 87: 377-389

4. Caro JF, Sinha MK, Kolaczynski JW, Zhang PL, Considine RV (1996) Leptin: The tale of an obesity gene. Diabetes 45: $1455-1462$

5. Ogawa Y, Masuzaki H, Isse N et al. (1995) Molecular cloning of rat obese cDNA and augmented gene expression in genetically obese Zucker fatty ( $\mathrm{fa} / \mathrm{fa}$ ) rats. J Clin Invest 96 : $1647-1652$

6. Masuzaki H, Ogawa Y, Isse N et al. (1995) Human obese gene expression: Adipocyte-specific expression and regional differences in the adipose tissue. Diabetes 44: 855858

7. Taylor SI, Barr V, Reitman M (1996) Does leptin contribute to diabetes caused by obesity? Science $274: 1151-1152$
8. Campfield LA, Smith FJ, Guisez Y, Devos R, Burn P (1995) Recombinant mouse OB protein: evidence for a peripheral signal linking adiposity and central neural networks. Science 269: 546-549

9. Tartaglia LA, Dembski M, Weng X et al. (1995) Identification and expression cloning of a leptin receptor, OB-R. Cell 83: $1263-1271$

10. Chen H, Charlat O, Tartaglia LA et al. (1996) Evidence that the diabetes gene encodes the leptin receptor: identification of a mutation in the leptin receptor gene in $\mathrm{db} / \mathrm{db}$ mice. Cell 84: 491-495

11. Lee GH, Proenca R, Montez JM et al. (1996) Abnormal splicing of the leptin receptor in diabetic mice. Nature 379: 632-635

12. Chua SC Jr, Chung WK, Wu-Peng XS et al. (1996) Phenotypes of mouse diabetes and rat fatty due to mutations in the OB (leptin) receptor. Science 271: 994-996

13. Takaya K, Ogawa Y, Isse N et al. (1996) Molecular cloning of rat leptin receptor isoform complementary DNAs identification of a missense mutation in Zucker fatty ( $\mathrm{fa} /$ fa) rats. Biochem Biophys Res Commun 225: 75-83

14. Woods AJ, Stock MJ (1996) Leptin activation in hypothalamus. Nature 381: 745

15. Mercer JG, Hoggard N, Williams LM, Lawrence CB, Hannah LT, Trayhurn P (1996) Localization of leptin receptor mRNA and the long form splice variant $(\mathrm{Ob}-\mathrm{Rb})$ in mouse hypothalamus and adjacent brain regions by in situ hybridization. FEBS Lett 387: 113-116

16. Vaisse C, Halaas JL, Horvath CM, Darnell JE Jr, Stoffel M, Friedman JM (1996) Leptin activation of Stat 3 in the hypothalamus of wildtype and ob/ob mice but not $\mathrm{db} / \mathrm{db}$ mice. Nature Genet 14: 95-97

17. Chilardi N, Ziegler S, Wiestner A, Stoffel R, Heim MH, Skoda RC (1996) Defective STAT signaling by the leptin receptor in diabetic mice. Proc Natl Acad Sci USA 93: 6231-6235

18. Satoh N, Ogawa Y, Katsuura G et al. (1997) The arcuate nucleus as a primary site of satiety effect of leptin in rats. Neurosci Lett 224: 149-152

19. Jacob RJ, Dziura J, Medwick MB et al. (1997) The effect of leptin is enhanced by microinjection into the ventromedial hypothalamus. Diabetes 46: 150-152

20. Considine RV, Sinha MK, Heinman ML et al. (1996) Serum immunoreactive-leptin concentrations in normalweight and obese humans. N Engl J Med 334: 292-295

21. Hosoda K, Masuzaki H, Ogawa Y et al. (1996) Development of radioimmunoassay for human leptin. Biochem Biophys Res Commun 221: 234-239

22. Hiraoka J, Hosoda K, Ogawa Y et al. (1997) Augmentation of obese (ob) gene expression and leptin secretion in obese spontaneously hypertensive rats (obese SHR or Koletsky rats). Biochem Biophys Res Commun 231: 582-585 
23. Maffei M, Halaas J, Ravussin E et al. (1995) Leptin levels in human and rodent: measurement of plasma leptin and ob RNA in obese and weight-reduced subjects. Nature Med 1: 1155-1161

24. Frederich RC, Hamann A, Anderson S, Lollmann B, Lowell BB, Flier JS (1995) Leptin levels reflect body lipid content in mice: evidence for diet-induced resistance to leptin action. Nature Med 1: 1311-1314

25. Maffei M, Stoffel M, Barone M et al. (1996) Absence of mutations in the human $O B$ gene in obese/diabetic subjects. Diabetes 45: 679-682

26. Considine RV, Considine EL, Williams CJ et al. (1995) Evidence against either a premature stop codon or the absence of obese gene mRNA in human obesity. J Clin Invest 95:2986-2988

27. Norman RA, Leibel RL, Devoto M et al. (1996) Linkage of obesity and energy metabolism to markers flanking homologous of rodent obesity genes is not evident in Pima Indians. Diabetes 45: 1299-1232

28. Niki T, Mori H, Tamori Y et al. (1996) Human obese gene molecular screening in Japanese and Asian Indian NIDDM patients associated with obesity. Diabetes 45: 675-678
29. Chua SC Jr, White D, Wu-Peng X et al. (1996) Phenotype of fatty due to Gln269Pro mutation in the leptin receptor (L epr). Diabetes 45: 1141-1143

30. Phillips MS, Liu Q, Hammond HA et al. (1996) Leptin receptor missense mutation in the fatty Zucker rat. Nature Genet 13: 18-19

31. Takaya K, Ogawa Y, Hiraoka J et al. (1996) Nonsense mutation of leptin receptor in the obese spontaneously hypertensive Koletsky rat. Nature Genet 14: 130-131

32. Considine RV, Considine EL, Williams CJ, Hyde TM, Caro JF (1996) The hypothalamic leptin receptor in humans: identification of incidental sequence polymorphisms and absence of the $\mathrm{db} / \mathrm{db}$ mouse and $\mathrm{fa} / \mathrm{fa}$ rat mutations. Diabetes 45: 992-994

33. Thompson DB, Ravussin E, Bennett PH, Bogardus C (1997) Structure and sequence variation at the human leptin receptor gene in lean and obese Pima Indians. Hum Mol Genet 6: 975-679

34. Kishimoto T, Akira S, Taga T (1994) Cytokine signal transduction. Cell 76: 253-262

35. McConkey EH (1993) Human genetics: the molecular revolution, Jones and Bartlett Publishers Inc., Boston, London 